\title{
Population Based Multicentric Survey on the Attitude and Knowledge of HIV/AIDS among Youth of the Three Senatorial Districts in Jigawa State, Nigeria
}

\author{
Garba Uba $^{1}$, A. Salisu ${ }^{1}$, Y. Abdulhadi ${ }^{1}$, Fatima I. Baiwa ${ }^{1}$ and Samira Mahad ${ }^{2}$ \\ ${ }^{1}$ Department of Science Laboratory Technology, College of Science and Technology, Jigawa \\ State Polytechnic, Dutse P.M.B. 7040, Jigawa State, Nigeria \\ ${ }^{2}$ Department of Biological Sciences, Kano State Collage of Education and Preliminary \\ Studies, P.M.B. 3145, Kano State, Nigeria \\ *Corresponding author
}

\begin{abstract}
A B S T R A C T
AIDS is still an incurable disease and is very costly to control. Since the first case of Acquired Immune Deficiency Syndrome (AIDS) in Nigeria was reported in 1986, the

Keywords

HIV/AIDS,

Knowledge,

Attitudes,

Transmission,

Multicentric survey

Article Info

Accepted:

15 March 2019

Available Online:

10 April 2019 human immune deficiency virus (HIV) infection has attained epidemic proportion. In an attempt to control this rapid spread, certain preventive measures have been developed. In spite of these and the campaigns to control it, the gap between the knowledge and attitudes of youths towards HIV/AIDS needs to be bridged. A Total of 1,500 One thousand five hundred youth between the age of 18- 50 from different educational levels of the three senatorial district of Jigawa state were approached. A structured questionnaire was issued to the respondents of two local Governments from each senatorial district. A clustered random sampling technique was employed for data collection. Our result showed that majority of youth within the age of 27- above have vast knowledge about HIV/AIDS and mostly lives in the urban areas. High percentage of youth $73 \%$ and $71 \%$ agree to live and share materials with people living with HIV/AIDS, even though misconception exist among rural dwellers about contracting the disease through eating, hugging and sharing of material. In conclusion, this study shows that although the awareness of HIV and its major routes of transmission are high in Jigawa State, there are gaps in the knowledge and attitudes of Youth of the state towards consequences of HIV and modes of transmission.
\end{abstract}

\section{Introduction}

Nigeria, with an estimated population of 160 million (National Population Commission, 2014), is second to South Africa in the number of people living with HIV/AIDS worldwide, representing 9 percent of the global burden of the disease. Since 1991, the country has employed a sentinel surveillance system among pregnant women age 15-49 attending antenatal care to track HIV prevalence. Surveillance results show that HIV prevalence has declined over the years, from 5.8 percent in 2001 to 4.6 percent in 
2008 and 4.1 percent in 2010. In 2010, across the country's states, HIV prevalence ranged from 1.0 percent in Kebbi to 12.6 percent in Benue (Federal Ministry of Health [FMoH], 2011).

HIV has been said to spread fastest and farthest in conditions of poverty, powerlessness and lack of information, which is the condition in which many young people especially in Nigeria and Jigawa live (FMOH, 2002). Nigeria has the second largest HIV epidemic in the world (NACA, 2017). Although HIV prevalence among adults is much less $(2.8 \%)$ than other subSaharan African countries such as South Africa (18.8\%) and Zambia (11.5\%), the size of Nigeria's population means 3.1 million people were living with HIV in 2017(UNAIDS, 2018). It is estimated that around two-thirds of new HIV infections in West and Central Africa in 2017 occurred in Nigeria. Together with South Africa and Uganda, the country accounts for around half of all new HIV infections in subSaharan Africa every year (UNAIDS 2017). This is despite achieving a 5\% reduction in new infections between 2010 and 2017(UNAIDS, 2018).

Unprotected heterosexual sex accounts for $80 \%$ of new HIV infections in Nigeria, with the majority of remaining HIV infections occurring in key affected populations such as sex workers (NACA, 2015). Six states in Nigeria account for $41 \%$ of people living with HIV, including Kaduna, Akwa Ibom, Benue, Lagos, Oyo, and Kano (NACA, 2017). HIV prevalence is highest in Nigeria's southern states (known as the South South Zone), and stands at $5.5 \%$. It is lowest in the southeast (the South East Zone) where there is a prevalence of $1.8 \%$. There are higher rates of HIV in rural areas (4\%) than in urban ones (3\%) (NACA, 2015). Despite the highest population of people living with HIV, the knowledge of HIV/AIDS and uptake of voluntary counseling and testing (VCT) is still low, especially in the rural areas.

A study by Iliyasu et al., (2006) among 210 adults in Danbare village, northern Nigeria, shows that majority of respondents did not know the causative agent of AIDS; however, knowledge of route of disease transmission was high, with majority of study participants mentioning sexual activity and unscreened blood transfusion, as possible transmission routes. Respondents listed avoidance of premarital sex, outlawing prostitution, condom use and screening of blood before transfusion as protective measures (Omokhodion et al., 2007).

In another similar study by Omoyemi et al., 2013, reported that although studies confirmed a high knowledge of HIV among Nigerian youth, there is a lag in linking HIV/AIDS knowledge with protective sexual behavior. The study utilized data from the Nigeria 2007 National HIV/AIDS and Reproductive Health Survey (NARHS). Regardless of HIV knowledge, higher education, older age at first sex, higher wealth index and urban residency are significant predictors of engagement in non-protective sexual behavior. The aim of this survey is to investigate the attitude and knowledge of HIV/AIDS among the youth multicentric population in the three senatorial districts in Jigawa state.

\section{Materials and Methods}

\section{Study area}

Jigawa State is in the North-western part of Nigeria; created out of the old Kano State in August 1991.The state comprises of 27 Local Government Councils and has a total population of 4,348,649 inhabitants. There were 2,215,907 males as opposed to 
2,132,742 females (NPC, 2006). Politically its divided into three senatorial districts Birnin Kudu, Buji, Dutse, Gwaram, Kiyawa, Jahun, Miga From South-West senatorial district, Auyo, Birniwa, Guri, Hadejia, Kaugama, K/Hausa, K/Kasamma, M/Madori From The North-East And Babura, Gagarawa, Garki, Gwiwa, Kazaure, Maigatari, Roni, Ringin, S/Tankar, Taura, Yankwashi, Gumel From North-West. About 80 per cent of the population is found in the rural areas and predominately farmers and Muslims. Jigawa shares an international border with Zinder Region in The Republic of Niger, which is a unique opportunity for cross-border trading activities. The socio-cultural situation in Jigawa State could be described as homogeneous: it is mostly populated by Hausa/Fulani, who can be found in all parts of the State.

\section{Sample size}

A Total of 1,500 One thousand five hundred youth between the age of 18-50 from the three senatorial district were approached. A structured questionnaire was issued to the respondents of two local Governments each from each senatorial district. The local government was randomly selected so that each local government has equal chance of being in the population. The individual consent was sought following ethical approval by the Hospital Medical Advisory Committee. Individual consent form was filled during the collection of sample to obtain information on demographic data such as age and sex, attitude, acknowledge and reproduction health.

\section{Sampling technique}

A clustered random sampling technique was employed. Based on that, two Local Governments were randomly selected from the three senatorial districts. They were Dutse and Miga from south-west, Hadejia, and
$\mathrm{K} / \mathrm{Hausa}$, from the north-east and Kazaure and Gumel from north-west. Two hundred and fifty (250) questionnaires were distributed to the youth of each of the selected local government and a total of 1425 questionnaires were retrieved.

\section{Data collection}

A structured 35 item questionnaire divided into three sections (excluding the demographic section) was used for data collection. It comprised of 27 questions on knowledge of HIV, 8 questions on attitude. The questionnaire was developed following extensive literature review and pre-tested for reliability and validity.

\section{Ethical consideration}

Ethical clearance for this research work was obtained from the ethical committee of Jigawa State Ministry of health in accordance with the code of ethics for biomedical research involving human subjects, before collection of samples. A standard questionnaire was administered to collect demographic data such as age and sex, attitude, acknowledge and reproduction health from all study subjects. The objectives of the study were explained to community leaders and local government executives before the permission was granted. Full verbal explanation of the study was given to members of selected households and consent was obtained before inclusion as participants. Respondents were given the right to refuse to take part in the study as well as to withdraw any time during the interview. Privacy and confidentiality were maintained throughout the study.

\section{Statistical analysis}

Data collected on the attitude and knowledge of HIV/AIDS among youth of the three senatorial districts in Jigawa state was 
subjected to relevant statistical tools at $\mathrm{P}$ values of $<0.05$ considered to be statistically significant.

\section{Results and Discussion}

Knowledge about HIV and AIDS was generally high in the three senatorial district of Jigawa (91\%). It was higher in the urban areas $(94 \%)$ compared to rural $(89 \%)$. It was also higher among males (92\%) than the females (89\%). However, the lowest proportion was recorded among respondents who never attended school $(77 \%)$ and highest among people with higher education (98\%). On the whole, youths (aged 15-19 years) had the lowest level of awareness (88\%). At zonal level, South-west had the highest level of awareness (97\%) and the least was recorded in North East (83\%).

Correct knowledge of HIV transmission is important in order to enhance effective preventive action. Respondents were asked to indicate how they thought a person could get the virus that causes AIDS. The routes of HIV transmission mentioned by the respondents included sexual intercourse $(87 \%)$, sharing of sharp objects (80\%), blood transfusion (73\%), sharing needles $(74 \%)$ and mother to unborn child $(55 \%)$. Less than half of the respondents $(49 \%)$ know all the five ways of transmitting HIV. Knowledge of all five routes of transmission was higher in the southern zones than in the north; in urban than rural areas and in persons with higher level of education.

The Nigerian Bureau of Statistics estimated that around two-thirds of new HIV infections in West and Central Africa in 2017 occurred in Nigeria. Together with South Africa and Uganda, the country accounts for around half of all new HIV infections in subSaharan Africa every year (UNAIDS, 2017. This is despite achieving a 5\% reduction in new infections between 2010 and 2017(NACA, 2017).
Six states in Nigeria account for $41 \%$ of people living with HIV, including Kaduna, Akwa Ibom, Benue, Lagos, Oyo, and Kano (NACA, 2017). HIV prevalence is highest in Nigeria's southern states (known as the South South Zone), and stands at $5.5 \%$. It is lowest in the southeast (the South East Zone) where there is a prevalence of $1.8 \%$. There are higher rates of HIV in rural areas (4\%) than in urban ones $(3 \%)$.

Despite the fact that Jigawa State House of Assembly has passed a bill which makes it compulsory for all intending couples to undergo test for HIV/AIDs, twice, in the last three months before marriage is contracted. There were no fewer than 5, 000 people registered to be living with the Acquired Immune Deficiency Syndrome (AIDS) in the state which account for $2.1 \%$ of the total Nigeria HIV prevalence(Daily Trust, Monday, 23/2015).

Awareness of HIV and AIDS was generally high among both sexes, across all the zones and age groups. However, it is worrisome to note a decline in most knowledge indicators from the 2014 values. For example, while in 2012, "AIDS has no cure" was reported by three quarters of the respondents, the proportion dropped to less than $70 \%$ in the 2014 survey. On what one can do to avoid getting infected with HIV and AIDS, $13 \%$ of the respondents still felt they would do nothing.

Knowledge of other indicators remained relatively similar to what was observed in the previous survey. Knowledge on how to prevent HIV infection was higher in males than in females. Knowledge on routes of transmission was generally high. However, some respondents had misconceptions including the perception that HIV can be transmitted by mosquito bites/bugs and by kissing (Fig. 1 and 2; Table 1 and 2). 
Table.1 Knowledge on the nature, prevention and transmission of HIV

\begin{tabular}{|c|c|c|}
\hline HIV Knowledge Items & Yes N (\%) & No $N(\%)$ \\
\hline $\begin{array}{l}\text { Knowledge of HIV } \\
\text { Ever heard of HIV? } \\
\text { Can you tell a HIV-infected person from his/her appearance? } \\
\text { Does HIV cause life-long infection? } \\
\text { Is HIV more easily transmitted than Hepatitis B virus? }\end{array}$ & $\begin{array}{l}1,042(91.6) \\
385(33.1) \\
759(51.8) \\
620(42.3)\end{array}$ & $\begin{array}{l}423(8.4) \\
1080(66.9) \\
706(48.2) \\
845(57.7)\end{array}$ \\
\hline $\begin{array}{l}\text { Knowledge of HIV transmission } \\
\text { Can HIV be transmitted through } \\
\text { Blood transfusion? } \\
\text { Sexual intercourse? } \\
\text { Breastfeeding? } \\
\text { From infected mother to unborn child? } \\
\text { Sharing razor blade, nail cutter, clipper? } \\
\text { Sharing toothbrush with infected persons? } \\
\text { Scarification marks and tattoos? } \\
\text { Male or female traditional circumcision? } \\
\text { *Sharing food with HIV infected person? } \\
\text { *Eating food cooked by HIV infected person? } \\
\text { *Hugging? } \\
\text { Kissing? } \\
\text { *Hand shaking? } \\
\text { *Mosquito bites? } \\
\text { *Witchcraft? }\end{array}$ & $\begin{array}{l}1,189(88.0) \\
1,221(90.2) \\
1,080(80.5) \\
1,064(79.5) \\
1,183(87.6) \\
1,038(77.7) \\
962(72.5) \\
978(73.6) \\
1,143(71.2) \\
1,237(77.6) \\
1,044(78.1) \\
624(49.4) \\
1,254(78.8) \\
1,082(67.0) \\
816(62.5)\end{array}$ & $\begin{array}{l}276(12.0) \\
241(9.8) \\
385(19.5) \\
401(20.5) \\
282(12.4) \\
427(22.3) \\
503(27.5) \\
587(26.4) \\
322(28.8) \\
228(22.4) \\
421(21.9) \\
841(50.6) \\
411(21.2) \\
383(33.0) \\
649(37.5)\end{array}$ \\
\hline $\begin{array}{l}\text { Knowledge of HIV prevention and control } \\
\text { Can HIV be prevented; } \\
\text { *Through vaccination? } \\
\text { Screening of pregnant women? } \\
\text { If HIV positive pregnant women receive treatment? } \\
\text { *If infants born to HIV positive mothers receive vaccination and } \\
\text { immunoglobulin at birth? } \\
\text { If HIV positive mothers do not breastfeed their babies? } \\
\text { If family members of HIV patients are screened for HIV? } \\
\text { Is there a medical treatment for HIV? } \\
\text { *Is there a possibility of a cure of HIV? }\end{array}$ & $\begin{array}{l}597(33.9) \\
1,288(81.1) \\
1,090(74.4) \\
945(64.5) \\
874(59.7) \\
294(13.2) \\
892(67.7) \\
738(43.5)\end{array}$ & $\begin{array}{l}868(66.1) \\
177(18.9) \\
375(25.6) \\
520(35.5) \\
591(40.3) \\
1,171(86.8) \\
573(32.3) \\
727(56.5)\end{array}$ \\
\hline
\end{tabular}

Table.2 Attitude towards persons living with HIV

\begin{tabular}{|l|c|c|}
\hline \multicolumn{1}{|c|}{ HIV Attitude Items } & $\begin{array}{c}\text { Disagree } \\
\text { N (\%) }\end{array}$ & $\begin{array}{c}\text { Agree } \\
\text { N (\%) }\end{array}$ \\
\hline Non-infected persons should not: & & \\
Live with HIV positive persons in the same place & $395(27.0)$ & $1,070(73.0)$ \\
Share cooking utensils with HIV patients & $478(32.6)$ & $987(67.4)$ \\
Eat food with HIV patients & $421(28.7)$ & $1,044(71.3)$ \\
Use the same toilet as HIV patients & $506(34.5)$ & $959(65.5)$ \\
Work in the same office as HIV patients & $381(26.0)$ & $1,084(74.0)$ \\
\hline
\end{tabular}


Fig.1 Age distribution characteristics of the population



Key: Series $1=\%$ total of the population, Series $2=$ total $\%$ of the SW, Series $3=$ total $\%$ of the NE; Series $4=$ total $\%$ of the NW

Fig.2 Educational characteristics of the population

\section{Educational Distribution of The population}

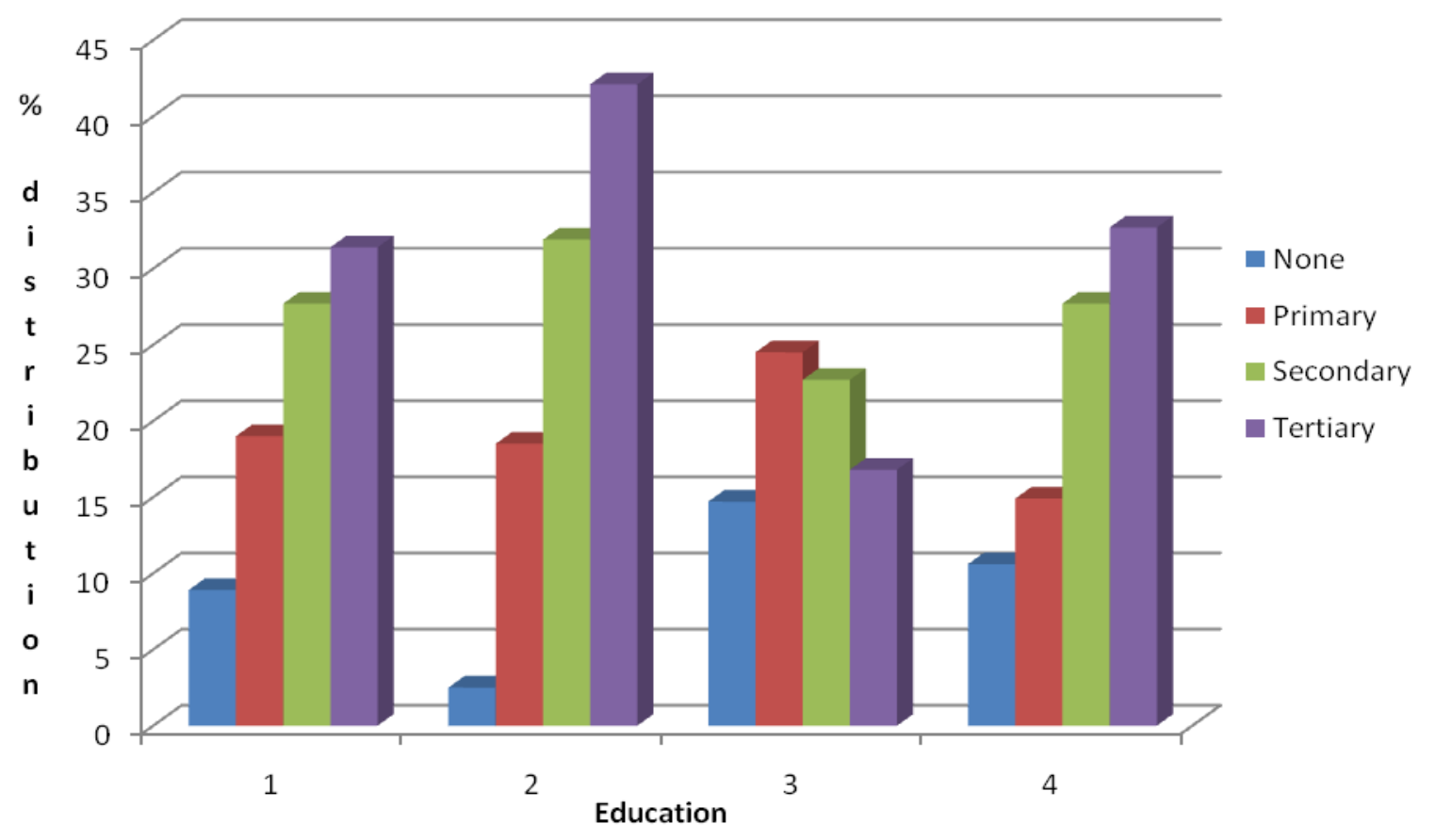

Key: $1=\%$ of the total population; $2=\mathrm{SW} \% 3=\mathrm{NE} \% 4=\mathrm{NW} \%$ 
These misconceptions and other decline in knowledge need to be addressed. Knowledge about HIV transmission among young people 15 to 24 years revealed a similar pattern to that of the general population (NAHRS, 2012).

Our study showed a similar finding of Okonkwo et al., (2017) good knowledge and attitudes of HIV amongst the youth of the three senatorial districts in Jigawa state. While knowledge of the common routes of HIV transmission such as sexual intercourse, blood transfusion, sharing of sharps, scarification and tattooing was high, misconceptions that HIV can be transmitted through hugging, hand shake, mosquito bites, eating or drinking in food and witch craft was also regular. This finding reveals higher percentages of people in the urban area with adequate knowledge of HIV/AIDs. In addition, low percentage of rural areas believes that HIV/AIDs can be transmitted by living or sharing materials with HIV/AIDs infected persons.

Ciccone et al., (2013) demonstrated that incorporating care managers into the health care system for the management of chronic diseases such as acute ischemic stroke improved patient's knowledge, self-efficacy and disease outcome.

Age varied significantly with knowledge with those aged 18-27years and above 57 years having lower scores. Persons in the former age group are more likely to be single while those in the later are more likely to have lost their partners considering the average life span of Nigerians is estimated at a little bit above 52 years (National Bureau of Statistics, Federal Ministry of Health (2016)

Education on HIV and related sexually transmitted diseases was recently incorporated in the Nigerian curriculum for primary and secondary schools, and the culture of marriage in Jigawa state, lack of adequately qualified teachers and counselors respectively are among the major dispute (Abba, 2013).

Majority of the respondents showed a negative attitude towards people living with HIV (PLWHA) which was more pronounced in the younger age group, persons with moderate education and those from the southern senatorial districts.

In conclusion, this study shows that although the awareness of HIV and its major routes of transmission are high in Jigawa State, there are gaps in the knowledge and attitudes of Youth of the state towards consequences of HIV and modes of transmission. There is need to develop community based awareness to educate the youth especially those living in the rural areas about the danger of this menace.

\section{Acknowledgement}

This project was fully funded by Tertiary Education Trust Fund (TETFUND), a parastatal of Federal Ministry of Education Abuja, Nigeria under Institutions Based Research (IBR) program Ref NO. TETFUND/DESS/POLY/DUTSE/RP/VOL.II. The authors also acknowledged the use of laboratory facilities from Jigawa state Polytechnic Dutse, Nigeria.

\section{References}

Abba RC (2013) The universal basic education programme and the family life HIV education in Nigeria. International Journal of Development and Sustainability 2: 766-776.

Adepoju, J. a. (2006). Knowledge of HIV/AIDS among nurses in southwestern Nigeria. The $A B N F$ 
Journal: Official Journal of the Association of Black Nursing Faculty in Higher Education, Inc, 17(4), 137-42. Retrieved from http://www.ncbi.nlm.nih.gov/pubmed/1 7252879

Aliyu, M. H., Varkey, P., Salihu, H. M., Iliyasu, Z., and Abubakar, I. S. (2010). The HIV/AIDS epidemic in Nigeria: progress, problems and prospects. African Journal of Medicine and Medical Sciences, 39(3), 233-239.

AVERT. (2015). HIV and AIDS in Nigeria. Averting HIV and AIDS: Global Information and Advice on HIV and AIDS. $\quad$ https://doi.org/10.1596/18139450-6869

Awofala, A. A., and Ogundele, O. E. (2015). HIV epidemiology in Nigeria. Saudi Journal of Biological Sciences. https://doi.org/10.1016/j.sjbs.2016.03.0 06

Ciccone MM, Aquilino A, Cortese F, Scicchitano P, Sassara M, et al., (2010) Feasibility and effectiveness of a disease and care management model in the primary health care system for patients with heart failure and diabetes (Project Leonardo). Vasc Health Risk Manag 6: 297-305.

Entonu, P. E., and Agwale, S. M. (2007). A review of the epidemiology, prevention and treatment of human immunodeficiency virus infection in Nigeria. The Brazilian Journal of Infectious Diseases: An Official Publication of the Brazilian Society of Infectious Diseases, 11(6), 579-90. https://doi.org/10.1590/S141386702007000600011

Federal Ministry of Health (FMOH). HIV/AIDS in Nigeria: Overview of the Pandemics. 2002;1-4.

Federal Ministry of Health [Nigeria]. 2011c. Technical report: National HIV sentinel survey among pregnant women attending clinics in Nigeria. Abuja, Nigeria: National AIDS/STI Control Programme and Federal Ministry of Health.

Fettig, J., Swaminathan, M., Murrill, C. S., and Kaplan, J. E. (2014). Global epidemiology of HIV. Infectious Disease Clinics of North America. https://doi.org/10.1016/j.idc.2014.05.00 1

FMOH. (2010). National HIV Seroprevalence Sentinel Survey: Technical report. Nigeria Federal Ministry of Health, Department of Public Health National AIDS/STI Control Programme. Retrieved from http://www.nigeriaaids.org/documents/2010_National HIV Sero Prevalence Sentinel Survey.pdf

Iliyasu, Z., Abubakar, I. S., Kabir, M., and Aliyu, M. H. (2006). Knowledge of HIV/AIDS and attitude towards voluntary counseling and testing among adults. Journal of the National Medical Association, 98(12), 1917-1922.

Isiugo-Abanihe, U. C. (2006). Sociocultural aspects of HIV/AIDS infection in Nigeria. African Journal of Medicine and Medical Sciences. Retrieved from http://ovidsp.ovid.com/ovidweb.cgi?T= JS\&PAGE=reference $\& D=$ emed $7 \&$ NE $\mathrm{WS}=\mathrm{N} \& \mathrm{AN}=18050775$

Jedy-Agba, E., and Adebamowo, C. (2012). Knowledge, attitudes and practices of AIDS associated malignancies among people living with HIV in Nigeria. Infectious Agents and Cancer, 7(1), 28. https://doi.org/10.1186/1750-9378-7-28

Kaugama, H. H., Idris, K. B., Othman, J., and Uli, J. A. (2012). HIV/AIDS Prevention: Influence of HIV Knowledge, Self- Efficacy, Parent and Peer influence, Social support, Culture and Government policy in Preventive Health Behavior in Jigawa State, Nigeria. International Journal of Basic and Applied Sciences, 1(4), 477-489. 
https://doi.org/10.14419/ijbas.v1i4.381

Maartens, G., Celum, C., and Lewin, S. R. (2014). HIV infection: Epidemiology, pathogenesis, treatment, and prevention. In The Lancet (Vol. 384, pp. 258-271). https://doi.org/10.1016/S01406736(14)60164-1

National Bureau of Statistics, Federal Ministry of Health (2016) The millennium development goals performance tracking survey report 2014. MDG survey report.

NACA (2017) National Strategic Framework on HIV and AIDS: 2017 - 2021 [pdf]

NACA (2015) Nigeria GARPR 2015' [pdf]

Ohnishi, M., Nakamura, K., Kizuki, M., Seino, K., Inose, T., and Takano, T. (2008). Caregivers' and non-caregivers' knowledge regarding HIV/AIDS and attitude towards HIV/AIDS and orphans in Nigeria. Health and Social Care in the Community, 16(5), 483-492. https://doi.org/10.1111/j.13652524.2007.00757.x

Okonkwo U, Ameh S, Out A, Okpara H (2017) HIV-Related Knowledge, Attitude and Practices of Healthy Adults in Cross River State Nigeria: A Population Based-Survey. J AIDS Clin Res 8:699. doi:10.4172/21556113.1000699

Okudo, Jerome and Ross, Michael. (2015). Knowledge and attitudes of young people in Nigeria about HIV/AIDS: a systematic review. Peak Journal of Public Health Management. 3. 1-9.

Omokhodion, F. O., Kayode, O. O., Ojanen,
M. a, and Barengo, N. C. (2007). Knowledge about HIV/AIDS and sexual practices among automobile repair workers in Ibadan, Southwest Nigeria. African Journal of Reproductive Health, 11(2), 24-32. https://doi.org/10.2307/ 25549713

Omoyeni, S. T., Akinyemi, A. I., and Fatusi, A. (2013). Adolescents and HIV-related behaviour in Nigeria: Does knowledge of HIV/AIDS promote protective sexual behaviour among sexually active adolescents? Etude de La Population Africaine, 27(2 SUPPL.), 331-342. https://doi.org/10.11564/27-2-478

Reis, C., Heisler, M., Amowitz, L. L., Moreland, R. S., Mafeni, J. O., Anyamele, C., and Iacopino, V. (2005). Discriminatory attitudes and practices by health workers toward patients with HIV/AIDS in Nigeria. PLoS Medicine, 2(8), 0743-0752. https://doi.org/10. 1371/journal.pmed.0020246

Umeh, C. N., Essien, E. J., Ezedinachi, E. N., and Ross, M. W. (2008). Knowledge, beliefs and attitudes about HIV/AIDSrelated issues, and the sources of knowledge among health care professionals in southern Nigeria. The Journal of the Royal Society for the Promotion of Health, 128(5), 233-9. https://doi.org/10.1177/1466424008092 793

UNAIDS 'AIDSinfo' [Accessed October 2018]

UNAIDS (2017) Data Book [pdf $\}$

\section{How to cite this article:}

Garba Uba, A. Salisu, Y. Abdulhadi, Fatima I. Baiwa and Samira Mahad. 2019. Population Based Multicentric Survey on the Attitude and Knowledge of HIV/AIDS among Youth of the Three Senatorial Districts in Jigawa State, Nigeria. Int.J.Curr.Microbiol.App.Sci. 8(04): 19111919. doi: https://doi.org/10.20546/ijcmas.2019.804.224 